\title{
The cup as metaphor and symbol: A cognitive linguistics perspective
}

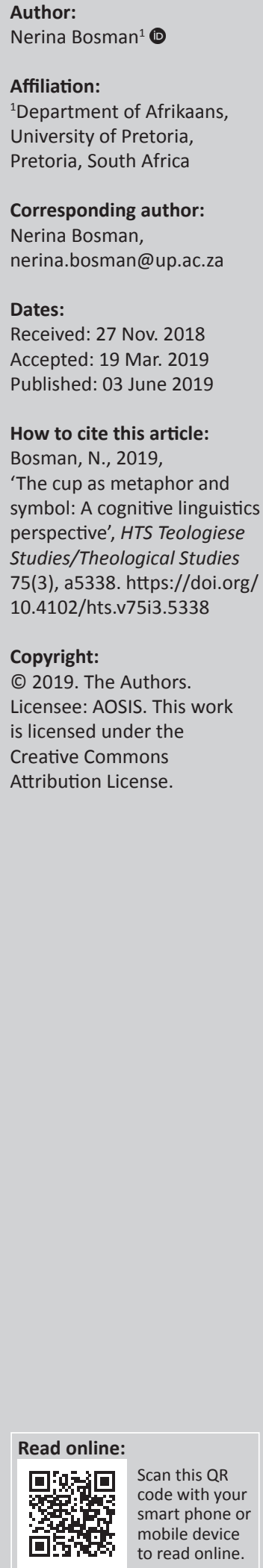

Although the Afrikaans word beker carries strong religious and other connotations, among them references to the Eucharist cup, the contribution of this article is to highlight, within a cognitive semantics framework, the role that cognitive mechanisms such as metaphor and metonymy played in the creation of this symbol. The article aims to illustrate the following: that the two signs of the Christian Eucharist, the bread and the wine, are grounded in conceptual metaphors of eating and drinking; that two conceptual drink metaphors are present when the symbol of the cup is analysed; that a related concept, that of metonymy, acts as a cognitive trigger, thus enabling the realisation of the symbol; and that other factors such as culture and religious symbolism played a significant role in the whole process. A corpus linguistics methodology is used to identify expressions containing the word beker. In analysing the expressions, Conceptual Metaphor Theory is used as a theoretical framework. It is found that conceptual metaphors such as nourishment is drinking and suffering is drinking underlie metaphoric expressions with beker. The metonymy container [the cup] for contained [the wine or blood] plays an important role in enabling the metaphors. In the images of the Eucharist cup and the broken bread, powerful metaphors arising from our bodily experience, denoting suffering and death on the one hand, and joy, nourishment and life on the other hand, are united to form the symbol.

Keywords: Cup; Metaphor; Metonymy; Cognitive Semantics; Symbol; Conceptual metaphor theory; Eucharist; Wine; Blood.

\section{Introduction}

When a very severe drought in South Africa was broken in January 2017, the front page of one of the Afrikaans newspapers ran with the caption: Ons beker loop oor [Our cup runneth over]. The occasion was the opening of the sluice gates in the Grootdraai Dam [the 'Big Bend Dam']. In Afrikaans, the expression my beker loop oor [my cup is overflowing] is often used in a nonreligious context, but always with definite allusions to the Bible text whence it originates Psalm 23. It often also conjures up a mental image or picture of a vessel overflowing - as is the case in the above example.

Another example of an intertextual reference to a Christian ritual involving bread and wine (and possibly also a cup or a glass) is found in the following Afrikaans poem where the literal meaning is quite explicitly profiled in the last two lines:

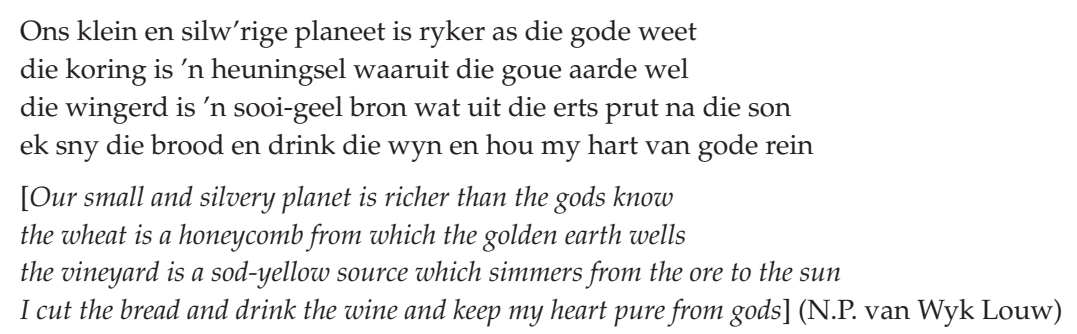

In this article, the semantic richness of figurative expressions in Afrikaans containing the word beker [cup] is explored, culminating in an account of how conceptual mechanisms like metaphor and metonymy enabled this word and its accompanying images to become such a powerful symbol in Western and Christian thought.

Although the cup has received much attention in academic writing, with the majority of the work focusing on the Eucharist of the New Testament, the contribution of this article is to analyse the cup as symbol and metaphor from a cognitive linguistic perspective by making use of Conceptual Metaphor Theory (CMT). 
I will argue:

- that the two signs of the Christian Eucharist, the bread and the wine, are grounded in conceptual metaphors of eating and drinking

- that two conceptual drink metaphors are present when the symbol of the cup is analysed

- that a related concept, that of metonymy, acts as a cognitive trigger or conceptual mechanism enabling the realisation of the symbol

- that culture and religious symbolism played a significant role in the whole process.

Central to the whole discourse will be the word beker [cup] and its denotation.

In the analysis that follows, a broad cognitive linguistics approach is used. Cognitive linguistics is the linguistic movement that started in the last quarter of the 20th century. It departs from the conviction that language must be seen as part of human cognition. During the rapid development of this approach, which led to new kinds of linguistics research practices, there was important cross-pollination between scholars hailing from fields apparently as diverse as neurology, psychology, anthropology, philosophy, speech therapy and linguistics - all endeavouring to understand human cognition and the part that language plays in our understanding of the world. In this endeavour, cognitive semantics has seen a flowering of which there are no signs of waning at present.

Of particular importance for cognitive semantics was Metaphors We Live By, written by George Lakoff and Mark Johnson, which burst onto the scene in 1980 with a plethora of quotes, such as the following one: 'Our ordinary conceptual system, in terms of which we both think and act, is fundamentally metaphoric in nature' (Lakoff \& Johnson 1980:3). In Lakoff (1987), CMT was developed further, and this theoretical framework has dominated current thinking about metaphor. In the following sections, some aspects of cognitive semantics, as they pertain to the central argument in this article, are briefly elucidated.

\section{The conceptual nature of language, metaphor and metonymy}

Cognitive linguists accept that language forms an important part of our conceptual system and that metaphor, in particular, forms part of cognition. Evans and Green (2006:156) explain that 'cognitive semantics sees linguistic meaning as a manifestation of conceptual structure: the nature and organisation of mental representation in all its richness and diversity'.

For more than 2000 years, metaphor has been an object of study in Western thought and, to quote Dirven and Paprotté (1985:vii), few subjects have proved more elusive. Despite this elusiveness, metaphor is nevertheless recognised as one of the deepest and most persistent phenomena of theory building and thinking.
Contrary to the traditional belief that metaphor transcends human experience and best reflects metaphysical truths, there is substantial evidence from cognitive science that demonstrates how metaphor is fundamentally a cognitive (and not a purely lingual) phenomenon (Lakoff \& Johnson 2003:246; Rohrer 2001).

In a 2003 Afterword to Metaphors We Live By, Lakoff and Johnson sum up developments in CMT, and show that empirical evidence points to the existence of the phenomenon called conceptual metaphor. We systematically use inference patterns from one conceptual domain to reason about another conceptual domain (Lakoff \& Johnson 2003:246). These systematic correspondences are called metaphorical mappings. This article provides examples of conceptual metaphors that reveal such systematic mappings from the source domain of eating and drinking to different target domains.

Today, CMT is not fundamentally contested, with renowned scholars such as Lakoff and Johnson (1980), Lakoff (1987), Kövecses (1986, 1995, 1999, 2002), Gibbs (1994, 1997, Gibbs and Steen $(1997)$ and Deignan $(2005,2008)$ to name but a few, still diligently exploring the insights into human thought that it offers.

Deignan (2008) succinctly sums up the path cognitive semantics has travelled:

It is now widely agreed that metaphor is a cognitive phenomenon and a mass of evidence has been accumulated to support the proposition that many linguistic metaphors, especially those that are most conventionalized and embedded in the language, are realizations of mental mappings. (p. 287)

Referring to Charteris-Black (2001), she adds that other factors, such as the linguistic context, genre and culture, also contribute to shaping metaphor.

In CMT, metaphor is understood as a mapping between two cognitive domains - a concrete source domain and an abstract target domain; it is experientially grounded, reflects embodied cognition and culture plays an important role. Well-known examples of conceptual metaphors are life is a journey and anger is heat. These conceptual metaphors are found in expressions such as She is boiling with anger, It's been a long, bumpy road and in the opening lines of Dante's Divine Comedy:

In the middle of life's road

I found myself in a dark wood.

Metonymy is another conceptual phenomenon which will be utilised in the analysis of the cup symbol. Linguistic metonymy is distinct from metaphor - it is referential in nature. It allows us to think of one thing in terms of its relation to something else with which it is closely associated, as in the following examples provided by Evans and Green (2006:313-314):

Place for institution: Buckingham Palace denied the rumours.

In this example, the place, Buckingham Palace, stands metonymically for the institution, namely, the British Monarchy.

Whole for part: My car has developed a mechanical fault.

Producer for product: She likes reading Shakespeare. 
As the title of the 2000 book Metaphor and Metonymy at the Crossroads (edited by Barcelona) implies, the cognitive paths of metaphor and metonymy often meet. Following the evolution of thinking concerning metaphor, thinking about metonymy (and its relation to metaphor) has also seen a process of development (cf. Gibbs 1994; Kövecses 2013; Kövecses and Radden 1998, among others).

Already in Lakoff and Johnson's Metaphors We Live By, attention was paid to metonymy as one of the conceptual mechanisms behind the semantic structure of language. That some kind of relationship does exist between metaphor and metonymy is a widely held assumption. Kövecses (2013) explores this relationship, referring to main streams of thought and offering his own views on this topic, stating as his main question 'whether metonymies play any role in the emergence of metaphors' (Kövecses 2013:75). This question lies at the heart of the current ongoing scholarly discourse.

Lakoff (1987:382) and Kövecses (2008:381) make use of metonymies such as body heat, internal pressure and agitation to show how metonymy can motivate metaphor. In their analyses, metonymic mappings provide mental access to, or the mental activation of, a target domain through a part of the same domain. They view metonymies as entry points into conceptual mappings.

Lakoff and Turner (1989:100-106) point out that metonymy, unlike metaphor, is not a cross-domain mapping, but instead allows one entity to stand for another because both concepts coexist within the same domain. As with conceptual metaphor, one can distinguish a source and a target in metonymical relations.

One entity stands for, and refers to another, but these entities do not belong to different domains (a more basic and a more abstract domain), as is the case with metaphor. As Evans and Green (2006:311) put it, 'while metonymy is the conceptual relation " $\mathrm{X}$ stands for $\mathrm{Y}$ ", metaphor is the conceptual relation "X understood in terms of Y"'. See also Gibbs (1994:319-324) regarding the distinction between metaphor and metonymy.

Conceptual metonymies such as a symbol and the person it stands for as in The Crown Can Appoint to the Garter (where Crown stands for the British monarch) and container and contained (that was an excellent dish) ${ }^{1}$ are mappings that occur within a single conceptual domain (Lakoff 1987:289). They provide mental access to a domain through a part of the same domain: 'the entity that is normally designated by a metonymic expression serves as a reference point affording mental access to the target (i.e., the entity actually being referred to)' (Langacker 1993:30). Kövecses and Radden (1998:39) point out that the vehicle as the entry point is highlighted. The part for whole relation illustrated by metonymies seems to be abundant in all languages.

Metonymy is a contiguous relationship such as between container and contained (cup and drink), but with metaphor 1.The examples are Dirven's (1985:96). there is a non-contiguous mapping between source and target domain and it is characterised by a 'major associative leap': in the metaphorical expression the hands of the clock the hand is no longer viewed as a body part (Dirven 1985:98).

Metonymy not only structures language, but also the language users' thoughts, attitudes and actions and, as many metaphors, are grounded in experience (Geeraerts 2010:214). When the two powerful cognitive processes, metaphor and metonymy, are found together, they almost guarantee that the conceptual projection (to borrow a word from Barcelona 2000:5) does not die.

\section{Embodiment and culture}

A prominent aspect of CMT is the role of the body in basic cognitive organisation, as a means of understanding 'the world we live by'. Scholars like Lakoff and Johnson (1980:246), Gibbs, Lima and Francoza (2004) and Kövecses (2008) argue that metaphorical mappings are not purely abstract and arbitrary, but shaped by our bodily experiences of the world. In numerous essays, articles and books reporting on research in a variety of languages, researchers have identified sets of conceptual metaphors for which the motivation seems not only to be very strongly linked to our physical experience of the world, but also to cultural aspects. As Gibbs (1997:146) puts it: 'Our understanding of what is conceptual about metaphor involves significant aspects of cultural experience, some of which is even intimately related to our embodied behaviour'.

\section{Drinking the cup: Metaphors of eating and drinking in Afrikaans}

My interest in linguistic expressions containing the Afrikaans word beker [cup] started with an investigation into eat and drink metaphors in Afrikaans, which, in turn, was inspired by Newman's 1997 and 2009 investigations into metaphors of eating and drinking. In a corpus linguistics study, Bosman (2015), building on Taljard and Bosman (2014), identified two groups of conceptual eat and drink metaphors in Afrikaans that are relevant to the current study: ${ }^{2}$

emotional or intellectual nourishment is eating/drinking and

emotional or spiritual suffering is eating/drinking

Newman (2009), in his work on the linguistics of eating and drinking across languages, identified certain conceptual categories of eating and drinking and grouped the metaphors that he found into these categories. The two conceptual metaphors above fit into two of the categories that he identified, namely, metaphors of internalisation (where the person eating experiences sensations of satiety and satisfaction) and metaphors of destruction (in cases where that which is eaten is quite literally destroyed by the eating process on the one hand, but where it can also destroy the eater on the other hand).

2.In this article, the convention started by Lakoff and Johnson (1980), which has become the general way to formulate conceptual metaphors, is followed: A is B. 
The bodily and cultural experiences of the processes of eating and drinking serve as motivation for the conceptual mappings between source domain and target domain. For example, the metaphors in the group emotional or spiritual suffering is eating/ drinking are motivated by the shared knowledge that imbibing liquids and food may not only lead to feelings of satiety, pleasure and altered states, but also that the food and drink which we consume may harm and even kill us.

Metaphoric expressions found in the Afrikaans corpora ${ }^{3}$, which contain, in addition to the word drink [drink], also the word beker [cup] caught my attention and called for further investigation. Examples from the corpora are as follows:

1. groot slukke uit hierdie beker vol troos drink [drink big gulps from this cup of comfort].

2. Ek sal die bitter beker ledig. [I will empty the bitter cup].

3. Jy sal nie ongestraf bly nie; drink sal jy die beker drink [You will not remain unpunished, you will have to drink the cup].

4. Ontwaak, ontwaak, staan op, Jerusalem, jy wat uit die hand van die HERE die beker van sy grimmigheid gedrink het; die kelk van bedwelming het jy uitgedrink, uitgesuig (Jes 51:17) [Awake, awake, stand up, O Jerusalem, which hast drunk at the hand of the Lord the cup of his fury; thou hast drunken the dregs of the cup of trembling, and wrung them out (Is 51:17)].

It can safely be assumed that many of the colloquial expressions with cup found in the Afrikaans corpora (like examples 1-4) originate from the Old and New Testament. This is not surprising, given the enormous influence that the Afrikaans translation of the Bible (1933) exerted on the formation of the Afrikaans lexicon, including its figurative expressions.

The act of drinking is either explicitly mentioned in the above examples (drink is often used as a collocate with beker) or implied. Metaphoric expressions with beker can, thus, be linked to the above-mentioned categories of eat and drink metaphors:

emotional or spiritual nourishment is drinking

All examples found in this category allude to Psalm 23:5 in the Old Testament:

5. Ná dié mondvol het sy beker steeds oorgeloop van opgewondenheid [After this mouthful his cup was still overflowing with excitement].

6. En toe ek hoor ons gaan boonop tussen die wingerde rondry en ook nog wyn proe, toe loop my beker oor! [And when I heard that we would also drive around in the vineyards and taste wine, my cup ran over!].

7. Iewers is ' $n$ beker wat oorloop, 'n sewende hemel en ' $n$ cloud nine [Somewhere there is a cup that runs over, a seventh heaven and a cloud nine].

One is also reminded of the Afrikaans expression 'om ' $n$ heildronk te drink' [to drink to someone's health] when 3.The Afrikaans corpora are available on the Viva website (https://vivaafrikaans.org/) celebrating something. The objects of the toast are usually not a prototypical drink, like water, but rather alcoholic beverages like champagne:

emotional or spiritual suffering is drinking

In the second group, the following examples which allude to, but are not from the Bible, were found:

8. Jy sal nie ongestraf bly nie; drink sal jy die beker drink [You will not remain unpunished, you will have to drink the cup].

9. As dit sou vereis dat hy ' $n$ beker tot die droesem moes ledig, dan sou hy dit doen [If this would require that he had to empty a cup that he would rather pass by to the bitter dregs, then this was what he would do].

But, as was expected, most examples in the corpora come from the Bible:

10. ' $n$ skroeiende wind: dit is die beker wat hulle sal drink (Ps 11:6) [and a horrible tempest: this shall be the portion of their cup (Ps 11:6, KJV)].

11. diep en wye beker vol angs en skrik (Esegiël 23:33) [the cup of astonishment and desolation (Ezk 23:33)]

12. Kan julle die lydensbeker drink wat ek drink (Mk 10:38; Mt 20:22) [Are ye able to drink of the cup that I shall drink of (Mt 20:22; KJV)].

Underlying all of the figurative expressions above is the powerful symbol of the Eucharist cup. In the next section, this aspect of the meaning of beker is further explored.

\section{The cup as symbol}

I will argue that where the linguistic item beker is the focus of figurative expressions (as in examples 5-12), the conceptual metaphors that are evident have a particularly strong cognitive power. It is not possible to understand the figurative expressions without knowing and having experienced the physical acts of eating and drinking. These physical notions are very strong, linked as they are to our instinct for survival. That one actually needs a vessel or container of some kind (and a hand can also be a container, as in the telling story of Gideon in the Bible) is as much part of our bodily experienceit is not very easy to drink directly from a source like a river or a puddle, for example - as it is part of cultural rituals involving drinking and eating. This deeply rooted knowledge is present in the metonymous relation between vessel (container) and content.

Central to this investigation is the literal object - the cup itself. In the next section, the polysemous nature of the word beker is briefly explored.

\section{Beker: object and symbol}

According to the Woordeboek van die Afrikaanse Taal I [Dictionary of the Afrikaans Language] (Schoonees 1970), beker has six polysemous senses, of which only the first two listed are of interest for this article, namely, (1) a deep vessel that contains liquids (note the example that is given - ' $n$ Beker vir die nagmaalswyn [a cup for the Holy Communion wine]) 
and (2) a cup-like object, with or without handles, usually in connection with sport matches, which acts as a trophy.

The referents of beker can be a mug, a jug, a wine cup or a trophy, for example. In contexts where it refers either to the cup of the Eucharist or to a trophy denoting victory, it is strongly associated with some kind of visual image or mental picture. ${ }^{4}$

Because so many of the expressions with beker that were found in the corpora come from the Bible, cup was also looked up in Strong's online Greek concordance. Under potérion [wine cup] a metaphorical meaning is listed: 'one's lot or experience, whether joyous or adverse, divine appointments, whether favourable or unfavourable, are likened to a cup which God presents one to drink: so of prosperity and adversity'. This rendering of the metaphorical meaning of cup neatly covers the two groups of conceptual metaphors identified above.

The physical object, the cup itself, when used in a religious context, carries a very specific symbolic meaning. I use the word symbol to refer to a sign that is understood to represent an idea or concept that goes beyond what can be seen in an image. Moreover, I understand the symbol of the cup as the end product of a cognitive process that involves both metaphor and metonymy and that carries with it a whole chain of associations, overlaid by a rich and ancient cultural tradition that transcends a specific language.

It is important to note here that in a specific New Testament religious context, the cup is not the only image with a symbolic meaning. The bread (referring also to the unleavened bread of the Pascha ritual) is of equal importance. These two images are closely linked. Both the wine in the cup and the bread belong to the domain of eating and drinking. In addition, they are both laden with religious significance.

\section{From object to symbol}

A central question is: how did the age-old symbolic meanings of cup evolve? Magennis (1985), in his study of the cup as symbol in Old English poetry and prose, pays special attention to two prominent images. The one image, that of a bright, gold-plated cup, conjures the world of the Germanic hall and banquet, where the cup is a symbol of 'a glorious life', prosperity, joy and ease (Magennis 1985:517). The other image is that of the poculum mortis, the death-bringing drink, found in patristic exegesis and spiritual commentary. This last image is linked very closely to Jesus' passion and death in the New Testament.

In the repeated re-enactment of the Last Supper ritual during Holy Communion, the bread and the wine are understood as

4.The trophy meaning and accompanying victory image is very frequent in one of the corpora that was used for data extraction, namely, a news copus, where references to sports events abound. Because the 'cup as trophy' is not the focus of this artice, to will no be I will not be analysing this particular usage, but it does offer another interesting topic to investigate, linking the image of the cup to those almost religious sport rituals which are so prevalent in our society. symbols of Jesus' sacrifice and death, but at the same time also as symbols of salvation and everlasting life. Conceptual metaphors clearly played a part in the creation of this symbol. Rooted deeply in age-old Judaic customs (the Pascha among others), the embodied source domains of eating and drinking are mapped on to the abstract target domains of (physical and spiritual) suffering and nourishment, death and grace. These metaphors are integrated or blended with Jesus' act and words and a new complex metaphor was created salvation and everlasting life is eating the bread and drinking the cup. In the formation of this metaphor, the other cognitive process mentioned above, namely, metonymy, is also at play. The container (the cup) stands for its content (some kind of liquid like wine). Cup and content as well as the act of drinking all belong to the same physical domain.

The process can be illustrated not only by following the events in the relevant passages from the New Testament, but also by keeping in mind the Old Testament where there are extremely strong and even violent connotations to the cup that God hands out. Magennis' twin images of the deathbringing cup of suffering and the cup of joy are kept in mind in the examples below.

\section{Cup of suffering}

To start the analysis, consider the following scene between Jesus and his disciples in Matthew 26. When Jesus says to James and John: 'Can you drink the cup I (am going to) drink?' and when he prays in Gethsemane as follows (Mt 26: 39): 'My father, if it is possible, may this cup be taken from me' (and note that in the Afrikaans translation of Matthew 20: 22, the word lydensbeker [cup of suffering] is used), he is clearly not referring to a physical cup, nor to the drink in the cup. Cup is used here to indicate his forthcoming suffering and death. How is this meaning being created? Within the cognitive semantics framework, we can conclude that conceptual metonymy (where the source, container - in this instance, the cup - stands for the target that which is contained) provides us with the route to the drink itself, thereby conjuring the image of Jesus drinking the contents. The conceptual metaphor emotional or spiritual suffering is drinking has now been activated. It is not the cup that might cause suffering, but that which is in the cup. ${ }^{5}$

Conceptual metaphors are often motivated, not only by our embodied experience, but also by our cultural beliefs and customs. When Jesus uses this figurative meaning of cup, he is referring to the Old Testament, where 'drinking the cup' may allude to God's wrath or punishment, as in the following verses.

Awake, awake, stand up, O Jerusalem, which hast drunk at the hand of the Lord the cup of his fury; thou hast drunken the dregs of the cup of trembling, and wrung them out (Is 51:17 KJV):

5.We find this same metonymy in the Afrikaans expression hy is lief vir die bottel [he loves the bottle], denoting a drunkard. 
15 For thus saith the Lord God of Israel unto me; Take the wine cup of this fury at my hand, and cause all the nations, to whom I send thee, to drink it.

16 And they shall drink, and be moved, and be mad, because of the sword that I will send among them.

17 Then took I the cup at the Lord's hand, and made all the nations to drink, unto whom the Lord had sent me:

18 To wit, Jerusalem, and the cities of Judah, and the kings thereof, and the princes thereof, to make them a desolation, an astonishment, an hissing, and a curse; as it is this. (Jr 25: 15 ff.; KJV)

31 Thou hast walked in the way of thy sister; therefore will I give her cup into thine hand.

32 Thus saith the Lord God: Thou shalt drink of thy sister's cup deep and large: thou shalt be laughed to scorn and had inderision; it containeth much

33 Thou shalt be filled with drunkenness and sorrow, with the cup of astonishment and desolation, with the cup of thy sister Samaria. (Ezk 23:31 ff.; KJV)

The analysis thus far shows that embodied experience and cultural knowledge both play a part in the formation of the metaphor emotional or spiritual suffering is drinking and that this process was possibly activated by the metonymies container for contained, cup for wine.

The languages of the Bible are ancient Hebrew and classical Greek - the expressions from this particular corpus are thus very old and originated in a culture vastly different from ours today. What is therefore interesting is the fact that figurative expressions with beker are alive and well in modern-day colloquial Afrikaans as evidenced by the data that were extracted from the corpora used. As has been pointed out, there are many examples in the Afrikaans corpus where beker [cup] is used to denote suffering. The conceptual metaphor is clearly a reliquary of a different time and culture which was transferred, by means of the Bible translation, into Afrikaans.

\section{Cup of blessing}

Yet another conceptual metaphor helps to form the symbol of the cup in the New Testament. In the following quote, Jesus equates the wine in the cup with his blood and by his actions and words he already foresees the future symbolic use of the bread and the wine:

27 And he took the cup, and gave thanks, and gave it to them, saying, Drink ye all of it;

28 For this is my blood of the new testament, which is shed for many for the remission of sins. (Mt 26:27-28)

Note the slight difference in Paul's retelling of the event in 1 Corinthians 15: 23-26 where, in addition to the metaphorical use (as in verse 25) also the metonymical use (in verse 26) of cup is clear:

23 That the Lord Jesus the same night in which he was betrayed took bread.

24 And when he had given thanks, he brake it, and said, take, eat: this is my body, which is broken for you: do this in remembrance of me.

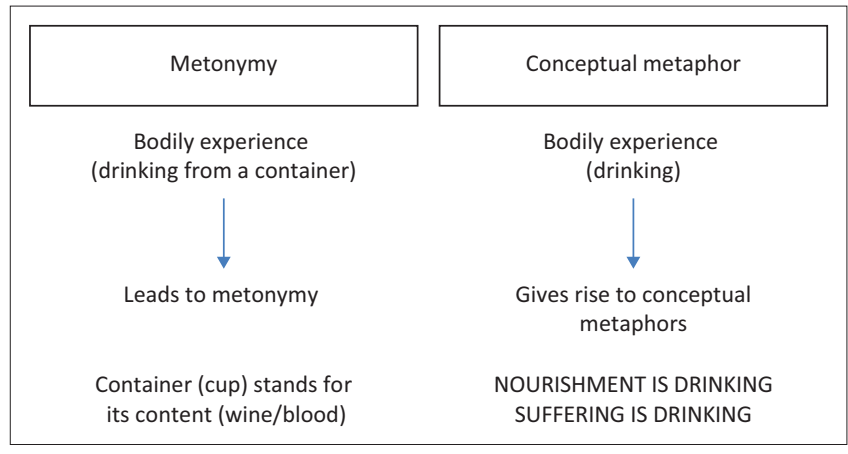

FIGURE 1: Cognitive processes in the formation of the symbol.

25 After the same manner also he took the cup, when he had supped, saying, this cup is the new testament in my blood: do this, as oft as ye drink it, in remembrance of me.

26 For as often as ye eat this bread, and drink this cup, ye do shew the Lord's death till he come.

According to Strong's online Greek concordance, the 'cup of blessing' (to poterion tes eulogias [the concecrated cup]) is a special use of the word in 1 Corinthians 10:16, and it means the cup for which we bless God, or which represents to us so much blessing from God.

When Jesus institutes the sacrament of the Eucharist, he uses the bread and wine as signs denoting his death, but not only his death. Bread and wine are also linked to the other powerful conceptual metaphor, namely that of nourishment or sustenance, and by extension, of life.

The metaphor is accompanied by visual images relating to the ritual that also act as aides-mémoire - the broken bread and the cup.

The whole process can be illustrated as follows (see Figure 1).

Starting with metonymy, and coupled with metaphors of eating and drinking, a complex metaphor is created by Jesus' actions and words during the Last Supper. This metaphor is linked to equally powerful metonymies of blood, where blood (inside the body) stands for life, but blood outside the body stands for death (Simó 2011). I argue that these strong conceptual tools enabled the symbol to come into being and to live on for more than 2000 years after it was first suggested.

The cup, rooted in the Christian belief system, later also gave rise to a rich medieval complex of stories, that of the Holy Grail - the grail being the cup that Jesus drank from at the Last Supper and which was used to catch his blood when he was on the cross.

\section{Conclusion}

The above analysis aimed to provide an answer to the question posed above: how did the age-old symbolic meanings of cup evolve? 
The analysis started, quite simply, with surface (lexical) realisations containing the word beker. These metaphorical expressions are linguistic instances of the underlying cognitive phenomena of conceptual metaphor and metonymy.

A question that is often asked in the scholarly debate regarding the relationship between metaphor and metonymy is the following: is the metonymy a 'conceptual prerequisite' (Barcelona 2000:31) for the metaphor? As is so often the case, Lakoff and Johnson (1980:40) provide a very convincing answer. They call cultural and religious symbolism special cases of metonymy and use the metonymy dove for Holy Spirit as an example. They explain that the symbolism is not arbitrary, but grounded in the conception of the dove in Western culture and the conception of the Holy Spirit in Christian theology. The dove (being a bird) has its natural habitat in the sky, which stands metonymically for heaven, the natural habitat of the Holy Spirit. That the Holy Spirit is linked not to any bird, but specifically to a dove, can further be explained by the cultural significance that the dove has within the context of the Bible - both in the Old and the New Testament.

Lakoff and Johnson (1980:40) conclude: 'The conceptual systems of cultures and religions are metaphorical in nature. Symbolic metonymies are critical links between every day experience and the coherent metaphorical systems that characterise religions and cultures'.

The above analysis showed that the symbol of the cup came into being through the conceptual mechanisms of metaphor, where our embodied experience of drinking motivates the conceptual metaphors linked to the cup. A powerful metonymy, where cup stands for that which is contained in the cup (either the bitter wine of God's punishment or wrath or the wine that provides pleasure and relief from thirst), links the cup to the conceptual metaphors.

An important realisation is that metaphors and metonymies are not necessarily verbalised in linguistic expressions. They may underlie many of our gestures (like pointing backwards when speaking of the past, for instance) or symbols. They are often strongly linked to a visual picture in our mind of objects in the world. When the cup, during the religious ritual of Holy Communion, takes central stage on the Eucharist table, it acts as a reminder, activating an underlying metonymic relationship which, in turn, is tied very strongly to a whole range of metaphors connected to eating and drinking. In other words, the vehicle as the entry point is highlighted. The cup is clearly profiled, resulting in perceptual saliency, which also strengthens the symbolism.

In the Judeo-Christian tradition, drinking, the cup, the wine in the cup and Jesus' blood form one continuous image rich in religious and cultural significance. The act of remembrance, repeated over and over, helped to establish the cup as one of the very strong symbols of Christendom. In the images of the Eucharist cup and the broken bread, powerful metaphors arising from our bodily experience, denoting suffering and death on the one hand, and joy, nourishment and (everlasting) life on the other hand, are united to form the symbol.

When the speaker in the poem by N.P. van Wyk Louw says he keeps his heart pure from the gods, he is nevertheless still conjuring up the images and the metaphors that underlie his actions in the poem - and if they still form part of our cultural and religious framework, we do remember.

\section{Acknowledgements Competing interests}

The author declares that she has no financial or personal relationship(s) that may have inappropriately influenced her in writing this article.

\section{References}

Barcelona, A. (ed.), 2000, Metaphor and metonymy at the crossroads: A cognitive perspective, Mouton de Gruyter, Berlin.

Bosman, N., 2015, 'EET en DRINK in Afrikaans - 'n leksikaal - semantiese ondersoek', Tydskrif vir Geesteswetenskappe 36(1), 123-145. https://doi.org/10.17159/22247912/2015/v55n1a9

Charteris-Black, J., 2001, 'Blood sweat and tears: A corpus based cognitive analysis of "blood" in English phraseology', Studi di Linguistica Teoretica e Applicata 30(2), 273-287.

Deignan, A., 2005, Metaphor and corpus linguistics, John Benjamins, Amsterdam.

Deignan, A., 2008, 'Corpus linguistics and metaphor', in R.W. Gibbs (ed.), The Cambridge handbook of metaphor and thought, pp. 280-294, Cambridge University Press, Cambridge.

Dirven, R., 1985, 'Metaphor as a basic means for extending the lexicon', in W. Paprotté \& R. Dirven (eds.), The ubiquity of metaphor. Metaphor in language and thought, pp. 85-120, John Benjamins Publishing Company, Amsterdam.

Dirven, R. \& Paprotté, W., 1985, 'Introduction', in W. Paprotté \& R. Dirven (eds.), The ubiquity of metaphor. Metaphor in language and thought, pp. vi-xi, John Benjamins Publishing Company, Amsterdam.

Evans, V. \& Green, M., 2006, Cognitive linguistics, an introduction, Lawrence Erlbaum, Edinburgh.

Geeraerts, D., 2010, Theories of lexical semantics, Oxford University Press, Oxford.

Gibbs, R.W., 1994, The poetics of mind, figurative thought, language, and understanding, Cambridge University Press, Cambridge.

Gibbs, R.W., 1997, 'Taking metaphor out of our heads and putting it in the cultural world', in R.W. Gibbs \& G.J. Steen (eds.), Metaphor in cognitive linguistics, pp. 145-166, John Benjamins, Amsterdam.

Gibbs, R.W., Lima, P.L.C. \& Francozo, E., 2004, 'Metaphor is grounded in embodied experience', Journal of Pragmatics 36, 1189-1210. https://doi.org/10.1016/ j.pragma.2003.10.009

Gibbs, R.W. \& Steen, G.J. (eds.), 1997, Metaphor in cognitive linguistics, John Benjamins, Amsterdam.

Kövecses, Z., 1986, Metaphors of anger, pride and love: A lexical approach to the structure of concepts, John Benjamins Publishing Company, Amsterdam.

Kövecses, Z., 1995, 'Anger, its language, conceptualization, and psychology in the light of cross-cultural evidence', in J.R. Taylor \& R.E. MacLaury (eds.), Language and the cognitive construal of the world, pp. 181-196, Mouton De Gruyter, Berlin.

Kövecses, Z., 1999, 'Metaphor, does it constitute or reflect cultural models?', in R.W. Gibbs \& G.J. Steen (eds.), Metaphor in cognitive linguistics, pp.167-188, John Benjamins, Amsterdam.
J

Kövecses, Z., 2002, Metaphor, a practical introduction, Oxford University Press, Oxford.

Kövecses, Z., 2008, 'Metaphor and emotion', in R.W. Gibbs (ed.), The Cambridge handbook of metaphor and thought, pp. 380-396, Cambridge University Press, Cambridge.

Kövecses, Z., 2013, 'The metaphor-metonymy relationship, correlation metaphors are based on metonymy', Metaphor and Symbol 28(2), 75-88. https://doi.org/10.108 based on metonymy', Metaph
$0 / 10926488.2013 .768498$

Kövecses, Z. \& Radden, G., 1998, 'Metonymy: Developing a cognitive linguistics view', Cognitive Linguistics 9(1), 37-77.

Lakoff, G., 1987, Women, fire, and dangerous things, The University of Chicago Press, Chicago, IL.

Lakoff, G. \& Johnson, M., 1980, Metaphors we live by, The University of Chicago Press, Chicago, IL.

Lakoff, G. \& Johnson, M., 2003, Metaphors we live by, The University of Chicago Press, Chicago, IL.

Lakoff, G. \& Turner, M., 1989, More than cool reason, a field guide to poetic metaphor, The University of Chicago Press, Chicago, IL.

Langacker, R.W., 1993, 'Reference point constructions', Cognitive Linguistics 4(1), 1-38. https://doi.org/10.1515/cogl.1993.4.1.1 
Magennis, H., 1985, 'The cup as symbol and metaphor in old English literature', Speculum 60(3), 517-536. https://doi.org/10.2307/2848173

Newman, J., 1997, 'Eating and drinking as sources of metaphor in English', Cuadernos de Filologia Inglesa 6(2), 213-231.

Newman, J., 2009, 'A cross-linguistic overview of "eat" and "drink"', in J. Newman (ed.), The linguistics of eating and drinking, pp. 1-26, John Benjamins, Amsterdam.

Rohrer, T., 2001, 'Understanding through the body, fMRI and of ERP studies of metaphoric and literal language', Paper presented at the 7th International Cognitive Linguistics Association conference, University of California at Santa Barbara, Santa Barbara, CA, July 2001
Schoonees, P.C. (ed.), 1970, Woordeboek van die Afrikaanse taal. Eerste deel A-C, Die staatsdrukker, Pretoria.

Simó, J., 2011, 'Metaphors of blood in American English and Hungarian, A crosslinguistics corpus investigation', Journal of Pragmatics 43(11), 2897-2910. https:// doi.org/10.1016/j.pragma.2011.05.004

Strong's Greek Concordance, viewed 08 August 2017, from https://biblehub.com/str/ greek/4221.htm.

Taljard, E. \& Bosman, N., 2014, 'The semantics of eating in Afrikaans and Northern Sotho: Cross-linguistic variation in metaphor', Metaphor and Symbol 29(3), 224-245. https://doi.org/10.1080/10926488.2014.924306 